\title{
WSPÓŁCZESNA PROZA SERBSKA I DYLEMATY POSTKOLONIALIZMU1
}

\author{
IGOR PERIŠIĆ ${ }^{2}$ \\ (Instytut Badań Literackich w Belgradzie)
}

\begin{abstract}
Słowa kluczowe: współczesna proza serbska, teorie postkolonialne, dyskurs bałkanistyczny, postmodernizm, neorealizm, zaangażowanie
\end{abstract}

Key words: contemporary Serbian fiction, postcolonial theories, Balkanist discourse, postmodernism, neorealism, engagement

\begin{abstract}
Abstrakt: Igor Perišić, WSPÓŁCZESNA PROZA SERBSKA I DYLEMATY POSTKOLONIALIZMU. „PORÓWNANIA” 16 (2015). T. XVI. S. 57-70. ISSN 1733-165X. W tekście zaprezentowano panoramę serbskiej prozy ostatnich dziesięcioleci ubiegłego i pierwszego dziesięciolecia XXI wieku z perspektywy teorii poskolonialnych. „Paradygmat zwierzęcy“ posłuży jako konstrukt formalny, wykorzystany w niniejszym tekście do rozważań nad formami współistnienia we współczesnej literaturze serbskiej tego, co osobiste, prywatne, swojskie, "udomowione“ z tym, co związane z demistyfikacją wielkich narracji nacjonalistycznych i neokapitalistycznych. Rozpoznania teoretyków postkolonializmu zostaną wykorzystane jako narzędzie metodologiczne służące do prezentacji strategii stosowanych w zaangażowanej refleksji nad globalnymi dylematami poetyki i polityki.
\end{abstract}

Abstract: Igor Perišić, THE CONTEMPORARY SERBIAN PROSE AND POSTCOLONIAL DILEMMAS. "PORÓWNANIA" 16 (2015). Vol. XVI. P. 57-70. ISSN 1733-165X.This paper presents a short panorama of Serbian literature of the last decade of the previous and the first decade of this century from the perspective of postcolonial theories. „The animal“ paradigm will serve as the formal construct, used in the present text for deliberations about forms of coexisting in contemporary Serbian literature of that which is personal, private, native, "domesticated ", which is

\footnotetext{
${ }^{1}$ Tekst jest zmienioną wersją artykułu: „Domaća književna životinja: Kratka panorama savremene srpske proze u svetlu postkolonijalnih i transkulturalnih kontroverzi". Transkulturna dimenzija slavističkih studija i komparationa književnost. Red. S. Vladiv-Glover, M. Ilišević, I. Perišić. Beograd: Institut za književnost i umetnost, 2014. S. 201-216.

2 Correspondence Address: perisigor@gmail.com
} 
associated with the demystification of great nationalist and capitalist narrative. The findings of theoreticians of postcolonialism are used as the methodological tool for the presentation of the strategy applied in employed reflection over global dilemmas of poetics and politics.

„Paradygmat zwierzęcy“ obejmujący swoiste bestiarium postaci, które pojawiły się w dziełach współczesnych pisarzy serbskich: kota Radoslava Petkovicia z Ogleda o mački (1995, Szkic o kocie), psa Milety Prodanovicia z Psa prebijene kičme (1993, Pies z przetrąconym karkiem), pijawki z powieści Davida Albahariego pod takim właśnie tytułem (Pijavice, 2005), człowieka-bestię Vladimira Arsenijevicia z książki Predator (2008) i czułego człowiek z Dneonika druge zime (2005, Dziennik drugiej zimy) Srđana Valjarevicia posłuży jako konstrukt formalny, wykorzystany w niniejszym tekście do rozważań nad formami współistnienia we współczesnej literaturze serbskiej tego, co osobiste, prywatne, swojskie, "udomowione“, z tym, co związane $\mathrm{z}$ demistyfikacją wielkich narracji nacjonalistycznych i neokapitalistycznych. Rozpoznania teoretyków postkolonializmu zostaną wykorzystane jako narzędzie metodologiczne służące do prezentacji strategii stosowanych w zaangażowanej refleksji nad globalnymi dylematami poetyki i polityki.

Tytułowy bohater książki Radoslava Petkovicia Szkic o kocie, od której rozpoczniemy rozważania, zwierzę, będące metaforą oswojonej przestrzeni intymnej, musi ją opuścić, by wyjść w wielki świat i zmierzyć się nie tylko z problemami rodzimymi, ale i globalnymi. $W$ świecie współczesnym bliskie nam, udomowione stworzenie, o którym mowa, ulega mutacji w człowieka jako największą dziką bestię, poświadczając w ten sposób śmierć (humanistycznego) subiektywizmu. Na planie społecznym zjawisko to daje się zinterpretować jako przemiany przebiegające od etycznego buntu przeciwko wojennym dyskursom kolonizacyjnym, poprzez przeciwstawne im procesy autointymizacji, aż do akceptacji konieczności antyautokolonizacyjnego wyjścia ku przewartościowaniu „dzikich“ globalistycznych narracji i powrotu do wyjściowej przestrzeni intymności.

We wstępie do swojej książki Krytyka postkolonialnego rozumu - kluczowego dzieła z zakresu teorii postkolonialnej - Gayatri Chakravorty Spivak podkreśla, że jej sprzeciw budzi zarówno kolonializm, jak i nacjonalizm (Spivak 7). W przypadku zastosowanego tutaj "zwierzęcego" konstruktu teroetycznego twierdzenie to można byłoby ująć następująco: paradygmat literackiego bestiarium umożliwia prezentację sposobów wyrażania w serbskiej literaturze współczesnej sprzeciwu wobec - z jednej strony - dyskursów nacjonalistycznych oraz - z drugiej strony globalistycznych.

$\mathrm{Na}$ pytanie dotyczące sposobów zastosowań teorii postkolonialnej w badaniach slawistycznych, Spivak odpowiada następująco: procesy kolonizacyjne na obszarach słowiańskich uwidaczniają się we wpływie wielkich imperiów: Austro- 
-Węgier, Imperium Otomańskiego oraz sowieckiego. Niezwykle istotny w tych rozważaniach jest fakt, że terminy "kolonizowany“ i "kolonizator“ w szerokim rozumieniu obejmują wszelkie procesy narzucania przez jedno państwo innym państwom praw i systemów edukacyjnych, efektem zaś takiej „kolonizacji w białych rękawiczkach“ jest wymierna korzyść ekonomiczna (Spivak 7). Jak zauważa badaczka: „Neokolonializm oznacza dla mnie przede wszystkim ekonomiczne, a nie terytorialne podboje imperializmu" (Spivak 3). Przywołane tutaj poglądy Spivak umożliwiają przyjrzenie się serbskiej prozie współczesnej, która usytuowana jest niejako "pomiędzy“ pozycją informatora autochtonicznego (czyli Innego, którego głosu nie rozumie zachodni podmiot kolonizujący, co skazuje Innego na zamknięcie $\mathrm{w}$ jego nacjonalistycznej utopii) i informatora dokonującego autokolonizacji (tego, który mniej lub bardziej dobrowolnie ulega wyżej opisanym nowym formom kolonizacji czy dyskursu bałkanistycznego, internalizowanego za pomocą stereotypów). Dyskurs bałkanistyczny stanowi wariant dyskursu orientalistycznego, o którym jako pierwszy pisał Edward Said: „Orientalizm to sposób myślenia oparty na ontologicznym i epistemologicznym rozróżnieniu pomiędzy „Wschodem" (w większości przypadków) a "Zachodem” (Said 31). Wychodząc od krytycznej analizy tego pojęcia, dokonanej na przykładzie Bałkanów przez Marię Todorową w jej słynnej książce Bałkany wyobrażone, Milica Bakić-Heyden usiłuje połączyć obie teorie. Wysuwa tezę mówiacą o tym, że uniwersalizm teorii Saida umożliwił odniesienie krytyki postkolonialnej do obszarów Bałkanów, a więc także Serbii:

Przenikanie się orientalizmu i bałkanizmu, w sposób jaki je postrzegam, w żaden sposób nie umniejsza wartości bałkanizmu jako autentycznego sposobu analizy tej specyficznej części Europy. Co więcej, wyodrębnianie i swoiste rozgraniczanie retoryki związanej z Bałkanami za pomocą pojęcia bałkanizmu, wprowadzonego przez znakomitą bałkańską intelektualistkę, Marię Todorovą, odgrywa wyjątkowe znaczenie jako przyczynek do autoprezentacji Bałkanów, będąc autentycznym bałkańskim głosem, istniejącym w opozycji do dyskursu o Bałkanach, stworzonego przez obcych. Dlaczego ta autoprezentacja (self-representation) jest taka istotna? Ponieważ, z jednej strony, przyczynia się do krytycznej analizy błędnych sądów innych o nas, dedykowanej nie tylko im, ale także tym, którzy nie zdają sobie sprawy z ich istnienia (przez co bezkrytycznie je internalizują i reprodukują, potwierdzając w ten sposób zawarte w nich "prawdy“), ale także, z drugiej strony, obnaża nasze przesądy na własny temat (z których niektóre są internalizowanymi bałkanizmami i orientalizmami) oraz całkowicie imaginacyjne autowyobrażenia (Bakić-Heyden 22).

Na planie poetyki "dialektyka zezwierzęcenia“ jawi się jako proces sprzeciwu wobec (serbskiej) literatury postmodernistycznej. To właśnie potrzeba "wyjścia“ kota $\mathrm{w}$ świat stanowi swoisty znak wyczerpania poetyki postmodernistycznej i ujawnienia potrzeby, aby literatura przemówiła (w kluczu neorealistycznym) 
o zdziczeniu rzeczywistości, w której powstawała. $\mathrm{W}$ tym sensie młode generacje pisarzy przeciwstawiają się Paviciowskiej „rozbuchanej“ fantastyce, ale powstająca jako wyraz tego sprzeciwu alternatywa nadmiernie jednak folguje felietonistycznemu realizmowi, przejawiającemu sie w braku literackości w literaturze (Nowak-Bajcar 2010: 42).

Literatura nawet wówczas, gdy w latach dziewięćdziesiątych XX wieku toczyła walkę $\mathrm{z}$ narracjami nacjonalistycznymi, opierając się traktowaniu sztuki jako azylu dla jurodiwych, wkraczała $\mathrm{w}$ obszar zarezerwowany dla podręczników demokracji i ludzkich praw. Poetyce postmodernistycznej przeciwstawiała neorealizm, neoweryzm czy nowy mimetyzm, czego najgłośniejszym autopoetyckim manifestem, któremu przyświecała idea przewartościowania paradygmatu narracyjnego, była powieść pt. Berlinsko okno (Berlińskie okno, 2005) Sašy Ilicia (Nowak-Bajcar 2012: 163-171). Niosła ona eksplicytnie wyrażony bunt przeciwko poetyce Milorada Pavicia oraz wzywała do poszukiwań prozatorskiego języka, umożliwiającego dotarcie do określonej prawdy narracyjnej, której postmodernizm deklaratywnie się wyrzekał. Tragiczny bohater tej powieści, Arif, zachwycał się rozprawą Platona pt. Obrona Sokratesa:

Inne książki opowiadały o miłości Hero i Leandra ${ }^{3}$ i można było je czytać od dowolnej strony, podczas gdy opowieść Platona biegła nieuchronnie niczym życie, $\mathrm{w}$ jednym kierunku. Podczas gdy inni, opisując swoich bohaterów, używali zbyt wielu epitetów, by udowodnić, że wymiary rzeczywistości można dowolnie zmieniać, język Platona cechowała krystaliczna przejrzystość i logika, a bohater starał się dotrzeć tylko do jednego celu, jakim jest prawda (Ilić 158).

Chociaż po strukturalistycznej zapowiedzi śmierci autora głoszenie wiary $\mathrm{w}$ istnienie jedynej prawdy, która ma wyłonić się $\mathrm{z}$ tekstu, wydaje się przejawem świeckiego prozelityzmu i pomimo tego, że wiara ta była wyrazem potrzeby sprostania wymogom haseł o odpowiedzialności i pojednaniu, taki „prawdokratyczny“ zwrot był bez wątpienia próbą odnowienia udręczonej prozy serbskiej, która zbliżała się do niebezpiecznej granicy zapaści oraz zamknięcia w sobie. U podstaw chęci zmiany paradygmatu literatury leżało zatem pragnienie powrotu do jej tradycyjnej czytelności, której rzekomo brakowało dziełom postmodernistycznym. Ale tę "czytelność" i popularność dedykowano przede wszystkim obserwatorom z zewnątrz, obcemu czytelnikowi, przez wzgląd na którego został wysunięty po-

3 Jest to nawiązanie do powieści Milorada Pavicia Roman o Heri i Leandru (Powieść o Hero i Leandrze), skonstruowanej w sposób, umożliwiający jej lekturę od przodu i - po odwróceniu książki - od tyłu. O trzech możliwych formach czytania: „klasycznym”, strona po stronie, poprzez wyszukiwanie tych samych haseł w trzech różnych typach źródeł oraz formie, umożliwiającej rozpoczęcie lektury w dowolnym miejscu wspomina także autor w poradach dla czytelnika, umieszczonych na wstępie słynnego Słownika chazarskiego (Hazarski rečnik, 1984) [przyp. tłum.] 
stulat uproszczenia języka. Hasła te niosły ze sobą przyzwolenie na zmianę statusu literatury $\mathrm{w}$ warunkach postsocjalistycznych, o czym pouczał serbskich pisarzy, opłakujących utracone dotacje od państwa, Andrew Baruch Wachtel (Wachtel), a co w praktyce sprowadzało się do podjęcia przez niektórych twórców decyzji o prowadzeniu walki literackiej poprzez udział w dyskusjach o postkolonializmie i wielokulturowości. Ten - być może - antyliteracki manewr wydał pewne owoce: zwięzły i jasny przekaz „usłyszeli“ ci, do których był adresowany, $\mathrm{w}$ przeciwnym razie, być może, nie byliby $\mathrm{w}$ stanie zrozumieć jednostkowego i zbiorowego dramatu lat dziewięćdziesiątych. Skoro zatem do tego, aby wezwać pomoc, wystarczą trzy słowa, może, mówiąc o współczesnej literaturze neorealistycznej w Serbii, powinniśmy używać bardziej swobodnego określenia: literatura SOS, spełniającego wszelkie kryteria lapidarności i prostoty?

Rozpoczynające Szkic o kocie motto autorstwa Alaina z Lille (1120-1203) stanowi zapowiedź sytuacji, która jest swoistą konstantą utworów postmodernistycznych:

Omnis mundi creatura

Quasi liber et pictura

Nobis est, et speculum

Nostrae vitae, nostrae mortis,

Nostri status, nostrae sortis

Fidele signaculum.

[Wszelkie stworzenia tego świata,

Niczym księga, obraz

Są dla nas, niczym lustro.

Naszego żywota, naszej śmierci,

Naszej pozycji, naszego losu

Wiernym są znamieniem]

Eseistyczna narracja Petkovicia rozpoczyna się zatem w duchu Borgesowskiego przekonania o obecnym w księgach świecie, któremu przysługuje status bardziej rzeczywistego od tego, który zwykliśmy uznawać za rzeczywisty, a więc w duchu Heglowskiej czy też biblijnej tezy o uprzednim w stosunku do świata sposobie istnienia ksiąg: „Na podobieństwo wszystkich innych, którzy w podobny sposob postrzegają rzeczywistość, książki o kotach zacząłem gromadzić jeszcze zanim stałem się właścicielem kota“. W drugiej połowie XX wieku przestrzeni tego heterokosmosu nie sposób było nie zapełnić elementami kultury popularnej, zatem narrator stwierdza dalej: „należę do osób, które swoje doświadczenia, nabyte za pośrednictwem książek, filmów, czy muzyki uznaję za równie ważne, jak doświadczenia, które zwykliśmy nazywać „życiowymi“ (Petković 7). 
W tym obciążąnym znaczeniowo wstępie książki pojawia się także postmodernistyczna problematyzacja statusu prawdy, przeprowadzona $\mathrm{w}$ duchu tradycji Umberto Eco:

To, co nazywamy własnym doświadczeniem, na które niekiedy się powołujemy, uznając je za pewien rodzaj mądrości, jest jedynie obrazem wydarzeń, sposobem, w jaki je zapamiętaliśmy - zawsze pozostaje tylko sposób, nigdy zaś sama rzecz, samo imię róży, wypowiadanie jej imienia - jeden z licznych możliwych sposobów pamiętania lub opowiadania o tym, co się wydarzyło (Petković 8).

Aby natomiast połączyć stany ontologicznego namysłu nad sposobami percypowania rzeczywistości i nad statusem prawdy, Petković decyduje się na indywidualną perspektywę, która unika ograniczeń wszechogarniającego (metanarracyjnego) spojrzenia: „Nie znamy świata, lecz tylko liczne opowieści o nim. - stwierdza Dlatego chcę mówić o świecie z powodu kota. Albo o kocie z powodu świata, nieważne. Wszystko jest zwierciadłem" (Petković 8). Pisze zatem genologicznie trudny do określenia tekst, na granicy fikcji i eseju czy wręcz nieprawowiernej pracy naukowej, tak bliskiej dokonaniom nowego historyzmu4.

Przez pryzmat tradycji Greenblattowskiej analizowane są także symboliczne związki kota i czarownicy (Greenblatt 65-109), nośny temat wykorzystywany przez postmodernistów do ironicznej reinterpretacji średniowiecznych poglądów antyprogresywistycznych. Uczynienie kota głównym bohaterem książki pozostaje w związku $\mathrm{z}$ antypatriarchalnymi narracjami emancypacyjnymi. Szczegółowy wywód poświęcony ekonomii braku korzyści z życia pod jednym dachem z kotem jest formą dyskusji ze zwolennikami idelogii krwi i ziemi, przywiązanymi z jednej strony do do tzw. wartości rodzinnych i jednocześnie pogardzającymi tymi, którzy znajdują miłość poza (mało)mieszczańskim światem Świętej Trójcy: mama-tata-dzieci.

Oprócz wszystkich tych wzorcowych postmodernistycznych strategii, książka Szkic o kocie, dzięki pozornie błahemu tematowi, wprowadza do literatury serbskiej - podobnie jak dzieła Svetislava Basary i Milety Prodanovicia z pierwszej połowy lat dziewięćdziesiątych - weryfikację wydarzeń związanych z ostatnimi bratobójczymi wojnami, którze towarzyszyły rozpadowi Jugosławii. Książkę rozpoczyna pobyt narratora w Zagrzebiu. W tamtym czasie (1990-1991):

Klepsydry w „Polityce“ wypełniały się imionami młodych ludzi - przyczyn śmierci nie wolno było podawać - którzy, o czym wszyscy wiedzieliśmy, ginęli na prawym brzegu

${ }^{4}$ Stephen Greenblatt podkreśla „literacki wymiar własnych tekstów, twierdząc, że u podstaw każdego tekstu stoi pragnienie opowiadania opowieści“. Milutinović, Zoran. „Poetika kulture Stivena Grinblata“. Reč 15 (1995). S. 58. Napisać tekst krytycznoliteracki albo historiograficzny oznacza opowiedzieć opowieść w formie krytycznoliterackiej albo historiograficznej. Z tego powodu do każdego swojego tekstu Greenblatt włącza także anegdoty, wskazując w ten sposob na to, jak trudno jest wytyczyć granicę pomiędzy narracja artystyczną i „naukową“. 
Dunaju. A w mieście doręczano wezwania mobilizacyjne, które oficjalnie były wezwaniami „do odbycia ćwiczeń wojskowych“. Niektórzy się stawiali, inni ukrywali; nie nocowano we własnych domach, nie zapalano świateł i nikogo nie wpuszczano do domów. Dżwięk dzwonka do drzwi i dzwoniącego telefonu, niegdyś budzące nadzieję, stały się teraz sygnałem pogróżki (Petković 16).

Jednak akcent nadal położony jest na tym, co intymne, na literaturze jako pewnej rzeczywistości, którą zakłóca ta "rzeczywista“:

Rozpocząłem tę historię od opowieści o początkach wojny, nie z potrzeby bycia w zgodzie z duchem czasów - ani po to, by mówić o polityce - ale dlatego, że wojna oznaczyła w moim życiu, podobnie jak w życiu każdego z nas, bolesne cięcie, po którym nic już nie będzie takie samo (Petković 27).

Są to niezwykle czytelne sygnały mówiące o konieczności wkroczenia literatury w świat, o wydostaniu się kota $\mathrm{z}$ „dwudziestu czterech ścian“5, i próby zmierzenia się z narracjami rzeczywistości, aby w końcowym efekcie zaproponować pozytywną odpowiedź albo znaleźć schronienie w Baudelaire'owsko-Andriciowskim obrazie kota, który mruczy wyłącznie dla człowieka.

Na wyzwania zdziczałej rzeczywistości lat dziewięćdziesiątych w sposób jeszcze bardziej eksplicytny odpowiedział Mileta Prodanović, wyrażając za pomocą figury psa potrzebę „oszczekania“ rzeczywistości. W powieści pt. Pas prebijene kičme (Pies z przetrąconym karkiem, 1993) znaleźć można krytyczne soliloquium intelektualisty (ukrytego pod maską Psa) przygniecionego przez brzemię historii (z przetrąconym karkiem), który zajmuje wyraźnie określone stanowisko ideologiczne. Tytułowa metafora jest figuralną transpozycją pieskiego życia odchodzącej w niebyt czy też nieistniejącej klasy mieszczańskiej: „Bezsilni, by się przyłączyć, żeby pobiec. Jedyne, co nam pozostało w świecie zdziczałego prymitywizmu, kipiącego i uzbrojonego po zęby kiczu, to porozumiewać się cicho skomląc" stwierdza narrator (Prodanović 288). Za sprawą manifestacyjnego zaangażowania odnosimy wrażenie, że powieść jest kulturalno-politycznym przewodnikiem dla cudzoziemców, pisanym w świadomym autokolonizacyjnym impulsie, w którym głębia zostaje zredukowana po to, by otworzyć przestrzeń szerokiej recepcji. Z drugiej jednak strony, podczas lektury takich książek z odleglejszej perspektywy uwidacznia się problem tzw. arystofanizacji pisma. Podobnie jak w twórczości antycznego komediografa, którego po przeszło dwóch i pół tysiącleciach ledwie możemy zrozumieć bez użycia obszernego aparatu naukowego, będącego egzegezą satyrycznych lamentów, tak i w tym przypadku, nawet po względnie krótkim

\footnotetext{
${ }^{5}$ Jest to określenie Igora Marojevicia, który w 1998 roku w powieści pod takim właśnie tytułem połączył problematykę najnowszej wojny i AIDS, umieszczając w centrum rozważań temat miłości, potraktowany w sposób pozbawiony ironii.
} 
czasie, inwektywy wymagają przypisów. "Zdziczałe“ lata dziewięćdziesiąte narzuciły potrzebę takich właśnie zaangażowanych książek, których autorzy problem ich estetycznego ukształtowania pozostawili na lepsze czasy. Narrator w autopoetyckiej refleksji problem ten uzasadnia następująco: wcześniej próbował - pod wpływem Joyce'a - pisać o rzeczywistości w sposób zawoalowany, humorystyczny, językiem zawiłym i hermetycznym, ale, jak stwierdza, „wszystko zaczęło tracić sens, ciężar przeciwko któremu próbowałem walczyć za pomocą humoru rozgałęział się, narastał, pokrywając moje niewystaczająco mocne spisy“ (Prodanović 198). W tamtym czasie literatura musiała zwiększyć moc swojego zaangażowania, aby jej głos stał się słyszalny.

Powieścią Pleši čudovište na moju nežnu muziku (Tańcz, potworze, do mojej subtelnej muzyki) z 1996 roku Prodanović udowadnia, że dzięki bicepsom uformowanym $w$ siłowniach rzeczywistości jest $w$ stanie zmierzyć się z figurą człowiekabestii (z którym w najostrzejszy konflikt wejdzie Vladimir Arsenijević w powieści pt. Predator). Uczynienie głównym bohaterem recydywisty, zabójcy, ubeka, tajemniczego i/lub trywialnego antybohatera, obdarzonego wrażliwością artystyczną, która popycha go ku zainteresowniom twórczością Paula Klee, było w tamtych czasach przejawem niezwykłej odwagi. Eksperymentując na granicy, po przekroczeniu której bohater negatywny przestaje być pociągający dla czytelnika - i nie zdoławszy ostatecznie (ani pod względem struktury tekstu, ani w aspekcie ideologicznym) osiągnąć wyznaczonego sobie ambitnego celu - Prodanović pokazał, że nawet $\mathrm{w}$ latach dziewięćdziesiątych można było połączyć zaangażowanie i oryginalną potrzebę reinterpretacji tradycji gatunku powieściowego. Tytuł jest autopoetyckim chwytem odmiennym od tego, który zastosowano w powieści Pas prebijene kičme: wyraża on ideę mówiacą o tym, że literatura w sympatyczny sposób (tytułowa/subtelna muzyka) próbuje doszukać się ludzkich stron bohatera, zmuszając go do tańca.

W powieści Prodanovicia z 2000 roku Ovo bi mogao biti vaš srećan dan (To mógłby być pana szczęśliwy dzień), opublikowanym po bombardowaniach NATO w 1999 roku, transparentne zaangażowanie, z którym mieliśmy do czynienia w powieści Pas prebijene kičme, ulega relatywizacji. Prowadzący narrację pies zaczyna teraz ujadać na wszystkich: i na domowników, i na obcych. Znaczący jest podtytuł utworu: Kolateralna knjiga opšte nekorektnosti (Kolateralna księga powszechnej niepoprawności), wskazujący na fakt poddania rzeczywistości literackiej ideologicznym i politycznym, humorystycznym modyfikacjom i satyrycznemu zakwestionowaniu w sposób o wiele bardziej niejednokierunkowy, niż miało to miejsce wcześniej, jeszcze zanim antynacjonalistycznie i proeuropejsko zorientowana część serbskiego społeczeństwa wypracowała potrzebę przewartościowania także narracji neoliberalnych.

Po zwierzętach domowych: kocie i psie, w serbskiej literaturze współczesnej pojawiły się bardziej tajemnicze pijawki, wyznaczające figuratywnie koniec pew- 
nego paradygmatu. W powieści Davida Albahariego Pijavice (2005) uwidacznia się wyraźna chęć narratora, aby opowiadać o kraju, państwie, Zemunie i o dotykającym współczesne społeczeństwo problemie antysemityzmu. Także i w tym utworze uwidacznia się chęć autora do podejmowania gry z czytelnikiem poprzez podwojenie perspektywy narracyjnej, zastosowanie gatunkowej niejednoznaczności utworu, w którym obecne są elementy thrillera i powieści miłosnej, napisanej z perpektywy tzw. słabego podmiotu męskiego. Głównym tematem książki jest autotematyczna refleksja nad zwrotem literatury ku współczesnym realiom, która prowadzi do wniosku o postmodernistycznej ambiwalencji wpisanej w potrzebę powrotu do rzeczywistości: „Nigdy rzeczywistość nie była bardziej odległa od rzeczywistości niż w tamtych latach w Belgradzie i nigdy wcześniej nie dokładano tylu starań, żeby ta rzeczywistość była jednak jedyną rzeczywistością" - stwierdza narrator powieści (Albahari 86).

Wspomniane podwojenie perspektywy narracyjnej na powieściowym metaplanie, odkrywa świadomość wyczerpania literatury postmodernistycznej. Z jednej strony, w sposób Baudrillardowski, poprzez obnażenie różnorodnych dystrybutywnych praktyk dyskursywnych, których celem jest zachowanie stanu symulakrum, zdiagnozowany zostaje stan hiperrelności panującej w Serbii w latach dziewięćdziesiątych. Z drugiej strony, chociaż perspektywa narracyjna nadal jest "niestabilna“ (co umotywowane zostaje oddziaływaniem marihuany na narratora), staje się zupełnie oczywiste, że nadszedł czas, by zaprzestać walki z symulakrum jego własną bronią, tzn. za pomocą postmodernistycznych strategii ludycznych i podjąć próbę przedstawienia „prawdziwej rzeczywistości“. Jednak jak zawsze, kiedy $\mathrm{w}$ utworach Davida Albahariego pojawia się temat miłości czy świata realnego, należy zachować czujność. Narrator powieści decyduje się bowiem na rodzaj coming out, ale robi to raczej niechętnie, jego prawdziwe "chcenia“ ciągle pozostają ukryte, a obecność wspomnianej drugiej perspektywy narracyjnej problematyzuje wiarygodność wydarzeń. Za jej pomocą metaforycznie opisane zostaje działanie tytułowych pasożytów wypijających krew, opijajających lub, bardziej precyzyjnie, mamiących narratora, który nadal pozostaje niestabilnym podmiotem, charakterystycznym dla prozy Albahariego. Pijawki z jego powieści działają nie tylko do „wewnątrz", są także figuratywnie skierowane na świat zewnętrzny - spijają one substancję rzeczywistości, w której byliśmy pogrążeni w latach dziewięćdziesiątych, a nawet stają się metanarracyjnymi pasożytami, wyznaczającymi kres słabego podmiotu, stającego w obliczu wyboru dwóch dróg. Jedna z nich prowadzi do jeszcze bardziej radykalnego postawienia problemu jego wyczerpania, w zasadzie do śmierci, jak w powieści Predator Vladimira Arsenijevicia, druga, jak w książce Dnevnik druge zime Srđana Valjarevicia, wiedzie do znalezienia sposobu jego odnowy.

Pierwsze ze wskazanych rozwiązań wybrał Vladimir Arsenijević, kreśląc portret człowieka-bestii w Predatorze (2008). Ponieważ, w odróżnieniu od Albaharie- 
go, Arsenijević jest pisarzem realistycznym, którego dzieła niewiele mają wspólnego ze strategiami postmodernistycznymi, zaangażownie $\mathrm{w}$ jego książkach $\mathrm{z}$ lat dziewięćdziesiątych (U potpalublju - 1994, Pod pokładem; Anđela - 1997, Aniela) jest łatwo dostrzegalne; przejawia się ono mianowicie w przekonaniu o istnieniu ścisłego podziału przebiegającego pomiędzy dobrem i złem. Sytuacja ta ulega zmianie, podobnie jak to miało miejsce w przypadku utworów Milety Prodanovicia, po bombardowaniach w 1999 roku. W 2000 roku Arsenijević publikuje powieść Mexico, dziennik wojenny, w którym próbuje odważnie wniknąć w sytuację pogardzanego wówczas (i nadal) Innego, Albańczyka z Kosowa. Może właśnie odwaga autora wymusiła na nim nadmierną stereotypizację tematu: książka, ukazująca się w edycji „Lodołamacz“ miała się nim stać, nie zaś mechanicznie odwracać wszystkie serbsko-albańskie stereotypy. Autor wykazał się dużą odwagą, która wówczas polegała na przeciwstawieniu się powszechnym sądom, zapomniał jednak o konieczności zweryfikowania zasad własnej reprezentacji politycznej, ukrytej pod maską rzekomo bezinteresownej troski o los człowieka. Dlatego w powieści, zamiast wiarygodnych portretów literackich, pojawia się idylliczny obraz relacji dwóch przyjaciół: Serba i Albańczyka, stanowiący w istocie egzemplifikację wyobrażeń zachodniego czytelnika na temat idealnego współistnienia różnych narodów na ziemiach byłej Jugosławii.

W odróżnieniu od tej książki, która w pewnym stopniu ulega stereotypom i wpisuje się $\mathrm{w}$ horyzont oczekiwań zachodniego czytelnika, Predatora można określić mianem pierwszej serbskiej powieści postkolonialnej, która zrywa z przesądami i zawodzi wspomniane oczekiwania. Na planie tematycznym pojawia się w niej szereg znaczących innowacji. Nigdy wcześniej na kartach dzieł literatury serbskiej nie zagościł temat terroru Irakijczyków wobec Kurdów, ludobójstwa Ormian w Turcji, realiów życia w berlińskich squotach czy brutalności tamtejszej policji. Kolonialne stereotypy uległy tutaj transgresji i modyfikacji $\mathrm{w}$ alterglobalistyczny dyskurs kultury popularnej. W częściach utworu rozgrywających się na anglojęzycznym obszarze językowym mamy do czynienia z mieszanką języka angielskiego i serbskiego, a gdy akcja przemieszcza się w inne przestrzenie, wymieszaniu ulegają także inne języki. Na poziomie chwytu literackiego ujawnia się całe bogactwo artystycznych strategii, odsyłających do tradycji modernizmu; chodzi mianowicie o Joyce'owskie przenikanie się różnorodnych świadomości narracyjnych, pojawianie się $\mathrm{w}$ opowiadaniach (rozdziałach powieści), których akcja zlokalizowana jest $\mathrm{w}$ różnych zakątkach świata, postaci z innych opowiadań, wypróbowywanie przez autora wielu konwencji literackich np. powieści epistolarnej, powieści strumienia świadomości czy powieści realistycznej lub kryminalnej... Wymóg postkolonialnej „poprawności“ sprawia, że w zakończeniu utworu, jak zauważa Saša Ćirić, „,nietrudno dostrzec swoistą kulturologiczną ironię - człowiek pochodzący z kraju dobrobytu i światowej hegemonii zostaje w sposób dosłowny zjedzony przez przedstawiciela Trzeciego Świata, pozbawionego praw i głodują- 
cego" (Ćirić). Ów subaltern-ludożerca rozpoczyna następnie nowe życie z zamiarem stworzenia szczęśliwej rodziny.

Tematem-matrycą jest zatem kanibalizm i autokanibalizm, a reinkarnacje tych wątków pojawiają się we wszystkich częściach świata: od Filadelfii, gdzie amerykański prezenter, pragnąc zostać zjedzonym, szuka do tego celu odpowiedniego predatora, aż do obszarów dzisiejszego Iraku i opowieści o Nihil Baksim. Ten ostatni zjada dziesięcioletniego Musę, adoptowanego sierotę i w ten sposób ulega przemianie w kanibala - Nihila Musę Baksiego, którego losy wiodą aż do Londynu. Podwojenie bohatera uwidaczniające się w zmianie jego imienia wyrażać ma niezbyt może odkrywcze przesłanie, mówiące o tym, że człowiek człowiekowi wilkiem, co jest głównym tematem książki. Pomimo wyraźnej schematyzacji, bogactwo technik narracyjnych i zaprezentowana szeroka panorama "ładu światowego" sprawia, że powieść jest nie tylko powierzchowną egzemplifikacją zadanego tematu, ale także przekonującym portretem człowieka-bestii. Za sprawą drugoosobowej narracji można odnieść wrażenie, że czytelnik jest ofiarą BogaPredatora - pisarza podsuwającego czytelnikowi niebezpieczną książkę, której nie uda mu się przeczytać w całości i pozostać przy życiu.

Największą wartością tej powieści jest ontologiczny strach, który wzbudza, wcale nie tak niewinną zabawą w narracyjno-metafizyczną dialektykę. Opowieść o człowieku jako dzikim zwierzęciu staje się zarazem łabędzim śpiewem człowieka jako twórcy oraz zapowiedzią potencjalnej śmierci czytelnika jako ofiary, porzuconej na pastwę Dyskursu-Bestii, pożerającej niegdysiejszy humanistyczny/humanitarny podmiot.

Odmienną wizję przynosi Dneonik druge zime (2005, Dziennik drugiej zimy) Srđana Valjarevicia. Kluczowy dla książki jest pojawiający się w tytule liczebnik. Po powieści Zimski dneonik (Zimowy dziennik) z 1995 roku, mając za sobą wielki życiowy dramat ${ }^{6}$, Valjarević zdecydował się ponownie napisać utwór przynależący do tego gatunku. Dla zrozumienia Dnevnika druge zime podstawowe znaczenie ma biografia autora (czy też cielesność książki), która spowodowała przerwę twórczą, twającą niemal dziesięć lat. Czasowa biograficzna i bibliograficzna „śmierć autora“ wyznaczyła pauzę, dzięki której także literatura otrzymała okazję do odkupienia: by wyruszyć nową, Inną drogą po raz drugi, by dzięki temu swoistemu manifestowi nowej utopii otrzymać okazję, by - zupełnie w duchu Rastka Petrovicia - nowi ludzie przemówili w sposób zupełnie nowy ${ }^{7}$. Ale ta nowa utopia nie do końca jest ponownie odnalezioną naiwnością, ponieważ, tautologicznie

\footnotetext{
${ }^{6}$ Mowa tu o kilkumiesięcznym paraliżu nóg, którego pisarz doświadczył w wyniku choroby alkoholowej [przyp. tłum.].

${ }^{7}$ Jest to aluzja do znanej powieści Rastka Petrovicia Ljudi govore (Ludzie mówią) z 1931 roku, przetłumaczonej na język polski jako Opowieść z podróży. Petrović, Rastko,.Opowieść z podróży. Przeł. H. Kalita. Warszawa: Czytelnik, 1973.
} 
rzecz ujmując, tylko raz można coś zrobić po raz pierwszy, o czym po mistrzowsku pisał Marcel Proust. Chociaż zdaniem Petera Sloterdijka prawdziwy początek nie istnieje, ponieważ każda egzystencja rozpoczyna się jeszcze przed narodzinami (Sloterdijik 24 f.), w samoświadomym wysiłku wirtualnego nowego początku mieści się utopia początku, w zasadzie zaś refleksja o początku drugiego stopnia, jako dojrzała i melancholijna świadomość konieczności dorastania, samoodkupienia i odnowy.

Cielesna autorefleksja urzeczywistnia się poprzez paradygmat rekonwalescencji. Przy użyciu militarystycznych terminów Petera Sloterdijka mowa tu o kulturologicznym paradygmacie przełomu dziesięcioleci; mobilizacja lat dziewięćdziesiątych wymusiła $\mathrm{w}$ latach dwutysięcznych rozbrojenie, $\mathrm{u}$ Valjarevicia znajdując wyraz w implicytnej poetyce skruchy. Wszyscy my nowi ludzie z Jugosfery jesteśmy moralnymi rekonwalescentami, a żeby o tym powiedzieć, oprócz wyeksponowania generacyjnych wypowiedzi o starzeniu się, konieczne było znalezienie nowej formy wyznania, niepatetycznej szczerości, w której literatura mogłaby przemówić o swoistej organicznej utopii, czyli minionych cielesnych i duchowych przygodach. W tym celu ironiczny postmodernizm musiał zostać pogrzebany, a intertekstualność należało wykorzystać nieco inaczej. Odnośniki zostały w tekście dziennika pominięte nie po to, by utworzył on Borgesowską babilońską bibliotekę, lecz, by tak rzec, z określonych powodów cielesno-terapeutycznych oraz literacko-rekonwalescencyjnych. Książki przywołane w Dnevniku druge zime mają działanie lecznicze, wzbudzają zachwyt, nie są zaś pretekstem do erudycyjnych popisów. "Ależ powieść!“ zachwyca się narrator dziełem Berlin Aleksanderplatz Alfreda Döblina, a o Dzienniku o Čarnojeviciu Miloša Crnjanskiego mówi, że go całkiem dosłownie przywrócił do życia. Mowa tu o nowym człowieku-narratorze, słuchającym tego, o czym mówią ludzie, także pisarze, ponieważ „Dobrze jest słuchać dobrych ludzi“" (Valjarević 89). Oprócz miłości do literatury zapowiada on także nadejście pisanej wielką literą Miłości, która jawi się migotliwie i swoją wyrazistą nieobecnością mówi o spoczywającej na niej obowiązku nowego utopizmu.

Być może z tego powodu konieczne było znalezienie formuły zbliżonej do nowego sentymentalizmu Mikhaiła Epsteina, za pomocą której zostaną wyrażone nowe (stare) emocje: „Tylko w uczuciach nie ma niczego nowoczesnego, nie ma ma w nich mody. One nigdy nie będą anachroniczne. W nich wszystko jest tak jak jest" (Valjarević 7). Pomimo uwidaczniającego się w tej wypowiedzi staromodnego, Nietzscheańskiego podejścia do uczuć, Valjarević znalazł jednak sposób, aby te stare i niezmienne emocje wyrazić za pomocą nowej figury zreinterpretowanej męskiej subtelności, będącej odzwierciedleniem przemian sposobu postrzegania mężczyzny, uwolnionego od konieczności zadośćuczynienia tradycyjnym patriarchalnym stereotypom. Na planie narracyjnym ten nowy, obdarzony delikatnością wzorzec męskości ujawnia się poprzez użycie zwrotów polegających na specyficznym, sprzecznym z logiką, nawracającym definiowaniu, zwrotów dla których, 
szukając w repertuarze tradycyjnej retoryki, trudno mi znaleźć adekwatne określenia:

Widzę za szybą galerii sztuki pewną dziewczynę, która siedzi przy stole i czyta książkę. Na ścianach wokół wiszą obrazy. Oprócz niej w galerii nie ma nikogo. Na zewnątrz tłok, na ulicach tłumy przechodniów. A ona sama, w środku. Siedzi i spokojnie czyta, ta dziewczyna pogrążona w ciszy (Valjarević 156).

Jest to zatem nowe, jeżeli tak można powiedzieć, zwykłe uniezwyklenie, kórego novum polega na postrzeganiu świata w sposób utopijnie naiwny, co stanowi prawdziwy post-postmodernistyczny cud:

Jak ja nieprawdopodobnie lubię te banany. Jak to możliwe, że istnieje coś, co ma taki smak i rośnie, a gdzieś tam ktoś to zbiera i wtedy jesz coś, co ma właśnie ten smak, który tak bardzo lubisz? Jak to jest? Albo pomarańcze? Jak to jest? Albo oliwki? A wszystko to odbierają ziemi i słońcu i dają ci, tak po prostu? Jak to jest? (Valjarević 120).

Przywołany sposób prowadzenia narracji dominuje w Dnevniku druge zime. Nie umiejąc znaleźć teoretycznego umocowania dla tej figury, figury piękna prostoty oraz pogodzenia z (urbanistyczną) naturą, jak również nie znajdując dla niej adekwatnego odpowiednika $w$ repertuarze literackich chwytów stylistycznych, nazwę ją po prostu Figurą Delikatności, która wieńczy „zoologiczny paradygmat" współczesnej literatury serbskiej, wskazując na to, że człowiek nie jest jednak taki zły, że istnieje sposób, żeby powrócił on do swoich filozoficzno-humanistycznych korzeni jako filozoficzne zwierzę, któremu trzeba nadać cielesną postać Czułego Innego.

Ttumaczenie z jezzyka serbskiego Sylwia Nowak-Bajcar

\section{BIBLIOGRAFIA}

Albahari, David. Pijavice. Beograd: Stubovi kulture, 2005.

Bakić-Heyden, Milica. Varijacije na temu 'Balkan'. Beograd: Institut za filozofiju i društvenu teoriju, „Filip Višnjić”, 2006.

Chakravorty Spivak, Gayatri, A Critique of Postcolonial Reason: Toward a History of the Vanishing Present. London - Cambridge MA: Harvard UP, 1999.

Chakravorty Spivak, Gayatri. „Predgovor izdanju na srpskom jeziku: U sećanje na Edvarda Saida”. Kritika postkolonijalnog uma. Przeł. Ranko Mastilović. Beograd: Beogradski krug, 2003. S. 57-63.

Ćirić, Saša. „Želudac humanosti”. Beton 60 (2008). Web. 05.07.2015 <http://www.elektrobeton.net/ anticement/zeludac-humanosti/>

Epstein, Michael. Postmodernizam. Przeł. R. Mečanin. Beograd: Zepter Book World, 1998.

Greenblatt, Stephen. „Szekspir i egzorcyści“. Przeł. K. Kwapisz Williams, Ł. Romanowski, A. Szwach, A. Wilson. Poetyka kulturowa. Pisma wybrane. Red. K. Kujawińska-Courtney. Kraków: Universitas, 2006. S. 65-109. 
Ilić, Saša. Berlinsko okno. Beograd: Fabrika knjiga, 2005.

Nowak-Bajcar, Sylwia. „Mapa pamięci. Serbska proza w poszukiwaniu pamięci kulturowej”. Topografia tożsamości. T. 1. Red. B. Zieliński. Poznań: Wydawnictwo Naukowe Uniwersytetu im. Adama Mickiewicza, 2012. S. 163-171.

Nowak-Bajcar, Sylwia. Mapy czasu. Serbska proza postmodernistyczna wobec wyzwań epoki. Kraków: Wydawnictwo Uniwersytetu Jagiellońskiego, 2010.

Pavić, Milorad. Stownik chazarski. Powieść leksykon w stu tysiącach słów. Przeł. E. Kwaśniewska, D. Ćirlić-Straszyńska. Warszawa: tCHu doM wYdawniczy, 1993.

Petković, Radoslav. Ogled o mački. Beograd: Vreme knjige, 1995.

Petrović, Rastko. Opowieść z podróży. Przeł. H. Kalita. Warszawa: Czytelnik, 1973.

Prodanović, Mileta. Pas prebijene kičme. Beograd: Plato, 1993.

Said, Edward. Orientalizm. Tłum. M. Wyrwas-Wiśniewska. Poznań: Zysk i S-ka, 2005.

Sloterdijik, Peter. Tetovirani život. Przeł. M. Soklić. Gornji Milanovac: Dečje novine, 1991.

Valjarević, Srđan. Dnevnik druge zime. Beograd: Samizdat B92, 2005.

Wachtel, Andrew Baruch. Remaining Relevant after Communism. The Role of the Writer in Eastern Europe. Chicago: University of Chicago Press, 2006. 